\title{
Nafion and modified-Nafion membranes for polymer electrolyte fuel cells: An overview
}

\author{
A K SAHU ${ }^{\dagger}$, S PITCHUMANI ${ }^{\dagger}$, P SRIDHAR ${ }^{\dagger}$ and A K SHUKLA* \\ Solid State and Structural Chemistry Unit, Indian Institute of Science, Bangalore 560 012, India \\ ${ }^{\dagger}$ Central Electrochemical Research Institute, Karaikudi 630 006, India
}

\begin{abstract}
Polymer electrolyte fuel cells (PEFCs) employ membrane electrolytes for proton transport during the cell reaction. The membrane forms a key component of the PEFC and its performance is controlled by several physical parameters, viz. water up-take, ion-exchange capacity, proton conductivity and humidity. The article presents an overview on Nafion membranes highlighting their merits and demerits with efforts on modified-Nafion membranes.
\end{abstract}

Keywords. Composite membrane; relative humidity; surface area; PEFC.

\section{Introduction}

Energy security ${ }^{\dagger}$ is one of the key challenges facing the mankind. A substantial proportion of our energy is met through fossil fuels derived from ultimately finite reserves and thus cannot be sustained indefinitely in the long-term. The deleterious effects of excessive consumption of carbonaceous fuels on the economy and ecology of a large part of the world is already apparent and well known to be recounted here. There is also a lurking fear that, at present and projected discovery, production and consumption rates, world oil-supply will fail to meet the demand in the near future. In response to these problems, green energy and sustainable living movements are gaining popularity. In recent years, while solar energy, geothermal energy, wind energy and fusion power technology have attracted attention, there is also increasing interest in hydrogen and its most efficient utilization in generating electrical energy. The latter is most appropriately achieved through fuel cells.

A fuel cell is an electrochemical power source with advantages of both the combustion engine and the battery. The difference between a battery and a fuel cell can be related to the definitions of a thermodynamic system and thermodynamic control volume (Mench et al 2008). In a thermodynamic system, no mass flux is permitted to cross the system boundaries like in a battery, while in a thermodynamic control volume, mass flux is permitted across the boundaries like in a fuel cell. Like a combustion engine, a fuel cell runs as long as it is provided fuel; and like a battery, fuel cells convert chemical energy

*Author for correspondence (akshukla2006@gmail.com)

${ }^{\dagger}$ Energy security refers to various security measures that a given nation, or the global community as a whole, must carryout to maintain an adequate energy supply directly to electrical energy. As an electrochemical power source, fuel cells are not subject to the Carnot limitations of heat engines. As early as in 1839, Sir William Grove discovered fuel cells by reversing water electrolysis to generate electricity from hydrogen and oxygen using an acid-electrolyte fuel cell. Since then fuel cell technology has evolved substantially.

Among the competing fuel cell technologies, polymer electrolyte fuel cells (PEFCs) are commercially most attractive owing to their quick start-up and ambienttemperature operations (Springer et al 1991; Gottesfeld and Zawodzinski 1997). PEFCs exhibit high-operational efficiencies with both specific and volumetric energydensities comparable to internal-combustion engines while emitting no pollutants (Grant 2003). The operating principle of a PEFC is depicted in figure 1.

At the interface between anode and the electrolyte, the fuel is converted into protons $\left(\mathrm{H}^{+}\right)$and electrons $\left(e^{-}\right)$, a process which is made possible by a catalyst that is typically Pt-based. Polymer electrolyte membrane allows protons to flow through, but prevents electrons from passing through it. Electrons travel to the cathode through an external circuit producing electrical current and $\mathrm{H}^{+}$ions (protons) pass through the membrane from anode to cathode, where they combine with oxygen molecules and electrons to form water.

The half-cell reactions taking place in a PEFC are

$$
\begin{array}{ll}
\text { Anode: } & \mathrm{H}_{2} \leftrightarrow 2 \mathrm{H}^{+}+2 e^{-} \\
\text {Cathode: } & 1 / 2 \mathrm{O}_{2}+2 \mathrm{H}^{+}+2 e^{-} \leftrightarrow \mathrm{H}_{2} \mathrm{O} \\
\text { Overall: } & \mathrm{H}_{2}+1 / 2 \mathrm{O}_{2} \leftrightarrow \mathrm{H}_{2} \mathrm{O} \quad \Delta G^{\circ}=-237 \mathrm{~kJ} / \mathrm{mol}
\end{array}
$$

The Gibbs free energy change $\left(\Delta G^{\circ}\right)$ of reaction (3) is related to the cell voltage by 


$$
\Delta G^{\circ}=-n F V_{0}
$$

where $n$ is the number of electrons involved in the overall reaction, $F$ the Faraday constant, and $V_{0}$ the cell voltage at thermodynamic equilibrium in absence of the current flow, i.e. under open-circuit condition. $V_{0}$ is the difference of the equilibrium electrode potentials at the cathode and the anode of the cell, and is calculated from

$$
V_{0}=-\Delta G / n F=1.23 \mathrm{~V}
$$

Although substantial improvements have been made in PEFCs, it has been difficult to realize them commercially owing to their cost. The estimated production cost per $\mathrm{kW}$ for a PEFC stack is presented as a Pi-chart in figure 2. It is obvious that the major cost of a PEFC stack is from membrane electrolytes, electrodes and bipolar plates (Tsuchiya and Kobayashi 2004). The following subsections describe Nafion and modified-Nafion membranes as electrolytes for PEFCs.

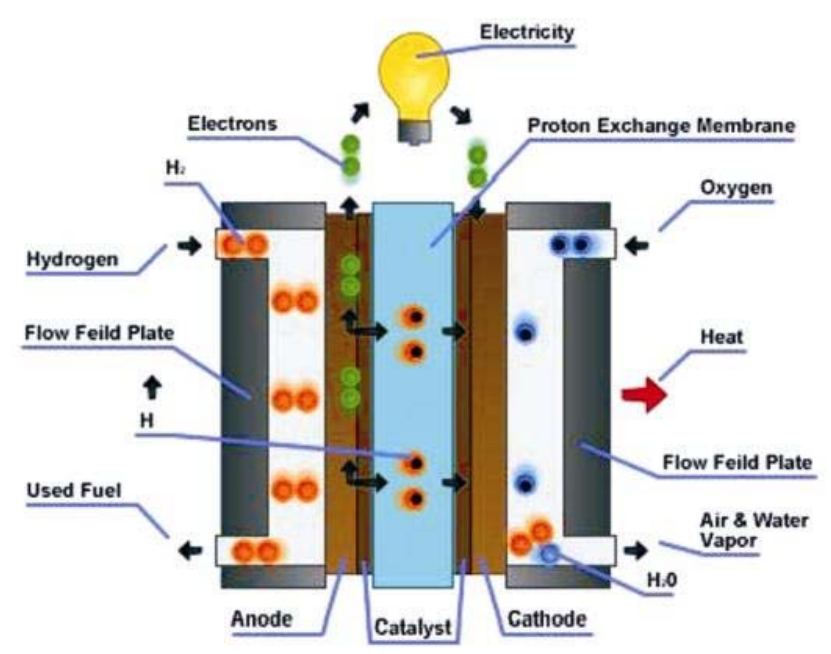

Figure 1. Schematic diagram of a PEFC.

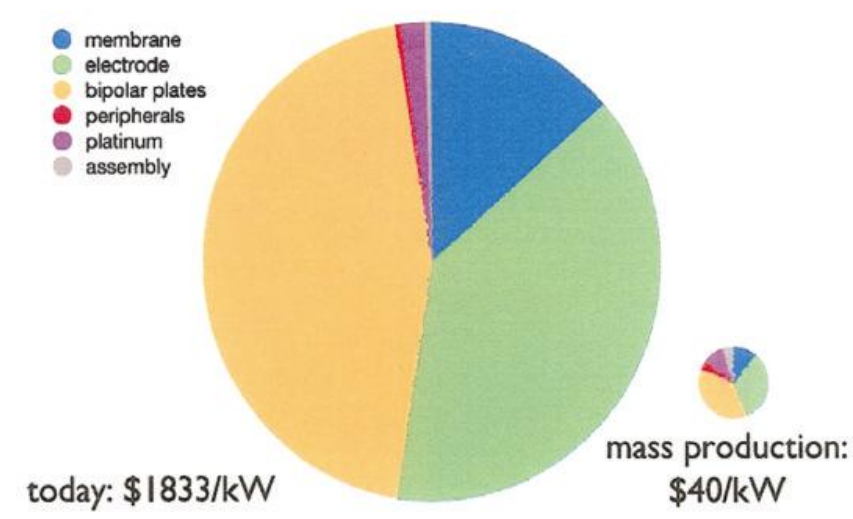

Figure 2. Estimated cost per $\mathrm{kW}$ for PEFC stack.

\section{Nafion membranes as electrolytes for PEFCs}

An effective membrane electrolyte for PEFCs, besides acting as a physical separator for the fuel and oxidant, must possess high ionic conductivity with little electronic component. It should be possible to cast them as thin and large surface-area membranes. The membranes should be stable in oxidizing and reducing environments prevailing during the operation of the PEFCs. The membrane must be easy to manufacture and be able to withstand the stress during electrode processing and attachment, and should be both mechanically and electrically robust to endure the start-up and shutdown schedules of the PEFCs.

As early as in $1940 \mathrm{~s}$, researchers were engaged in developing organic ion-exchange membranes for fuel cell applications (Grot 1985; Roziere and Jones 2003). These ion-containing polymers were termed as ionomers. It was believed that these ionomeric polymers would possess better properties, as they involve the interaction between polymer and ions. The earliest PEFC systems served as the power plants for Gemini space missions in the early 1960s. But the cells were short-lived due to the oxidative degradation of the membranes comprising a copolymer of sulfonated polystyrene and divinylbenzene. In the late 1960s, DuPont developed membranes from Nafion, a copolymer of perfluoro-sulfonic acid with hydrophobic fluorocarbon backbone and hydrophilic sulfonic acid pendent side chains. This membrane was primarily used as a perm-selective separator in chlor-alkali electrolysers. In 1980s, the use of Nafion membrane helped realizing the concept of 'zero-gap' cell design. With the induction of zero-gap cell concept, the internal resistance of the PEFCs decreased and, as a result, the overall efficiency of the system increased substantially (Shukla and Raman 2003). The chemical structure of Nafion is depicted in figure 3 .

Nafion is produced by co-polymerization of variable amounts of unsaturated perfluoroalkyl sulfonyl fluoride with tetrafluoroethylene. Nafion is commercially available in varying equivalent weights, viz. 900, 1100, 1200, etc. Equivalent weight $(\mathrm{EW})$ represents grams of dry Nafion per mole of sulfonic acid groups when the material is in the acid form. Nafion membranes employing polymer with $\mathrm{EW}=1100$ are listed in table 1 . These membranes

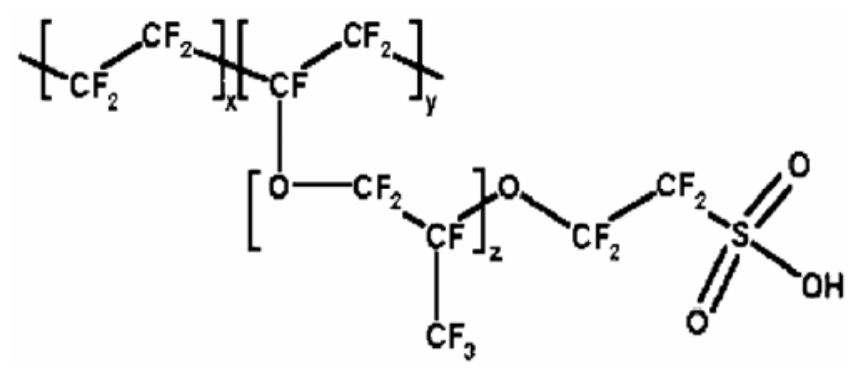

Figure 3. Chemical structure of Nafion. 
are widely used in PEFCs due to their high proton conductivity and moderate swelling in water (Hickner et al 2004; Mauritz and Moore 2004). Nafion-117 membrane employs the polymer with equivalent weight of 1100 and has a thickness of 7 mils $(1 \mathrm{mil}=1 / 1000$ of an inch $=$ $25.4 \mu \mathrm{m})$. Other cation exchange membranes with differing EWs of polymer and thicknesses designed for various applications are presented in table 2. Perfluorosulfonate cation exchange membranes with structures akin to Nafion have been developed by Asahi Chemical Company (Aciplex) and Asahi Glass Company (Flemion).

Nafion has $\sim 40 \AA$ clusters of sulfonate-ended perfluoroalkyl ether groups organized as inverted micelles arranged on a lattice (Hsu and Gierke 1983) as shown in figure 4(a). These micelles are connected by pores or channels of $\sim 10 \AA$ in size. These channels with $-\mathrm{SO}_{3}^{-}$ groups invoke inter cluster ion-hopping of positively charged species. A model for proton conduction in Nafion based on three different regions within the polymer membrane has been proposed in the literature (Yeo and Eisenberg 1997). These regions are fluorocarbon phase (FC), interfacial region (IF) and ionic clusters (IC). Figure 4(b) shows cluster-network model for the interactions between polymer and water in Nafion membrane (Hsu and Gierke 1983). In Nafion membrane, FC region consists of polymer backbone, viz. the PTFE backbone of Nafion, IF region contains side chains comprising water and sulphonate groups and IC region contains absorbed water.

Table 1. (a) Physical parameters of Nafion membranes

\begin{tabular}{lcc}
\hline $\begin{array}{l}\text { Membrane } \\
\text { type }\end{array}$ & $\begin{array}{c}* \text { Typical } \\
\text { thickness }(\mu \mathrm{m})\end{array}$ & $\begin{array}{c}\text { Basis } \\
\text { weight }\left(\mathrm{g} / \mathrm{m}^{2}\right)\end{array}$ \\
\hline Nafion -112 & 51 & 100 \\
Nafion -1135 & 89 & 190 \\
Nafion -115 & 127 & 250 \\
Nafion -117 & 178 & 360 \\
\hline
\end{tabular}

Table 1. (b) Physical properties of Nafion membranes.

\begin{tabular}{lc}
\hline Properties & Typical value \\
\hline Water uptake $\left(\%\right.$ water $\left.^{\mathrm{a}}\right)$ & 35 \\
Tensile modulus $(\mathrm{MPa})$ & 249 \\
$50 \% \mathrm{RH}\left(25^{\circ} \mathrm{C}\right)$ & 64 \\
Water soaked $\left(100^{\circ} \mathrm{C}\right)$ & \\
Tensile strength $(\mathrm{max} . \mathrm{MPa})$ & $43^{\mathrm{b}}, 32^{\mathrm{c}}$ \\
$50 \% \mathrm{RH}\left(25^{\circ} \mathrm{C}\right)$ & $25^{\mathrm{b}}, 24^{\mathrm{c}}$ \\
Water soaked $\left(100^{\circ} \mathrm{C}\right)$ & $2 \cdot 0$ \\
Density $\left(\mathrm{g} / \mathrm{cm}^{3}\right)$ & $0.6 \times 10^{-6}$ \\
${ }^{1} \mathrm{H}$ diffusion coefficients $\left(\mathrm{cm}^{2} / \mathrm{s}\right)$ & $0 \cdot 9$ \\
Ion exchange capacity $($ mequiv./g) & \\
\hline
\end{tabular}

${ }^{\mathrm{a}}$ Water uptake from dry membrane soaked in water at $100^{\circ} \mathrm{C}$ for $1 \mathrm{~h}$; ${ }^{\mathrm{b}}$ measured in machine direction; ${ }^{\mathrm{c}}$ measured in transverse direction, *at $25^{\circ} \mathrm{C}, 50 \%$ R.H.
A simple structural conceptualization of cross-linked polyelectrolyte and clustered ionomeric system with anionic side-chain (Yeo and Eisenberg 1997) is shown in figure 5; they have also studied the diffusion of water in Nafion by sorption from the contacting liquid into dry samples and measuring water uptake as a function of time in the temperature range between $0^{\circ} \mathrm{C}$ and $100^{\circ} \mathrm{C}$. The diffusion coefficient $(D)$ of water in the membrane was found to increase from about $10^{-6}$ to $10^{-5} \mathrm{~cm}^{2} / \mathrm{s}$ with increasing temperature, and the activation energy was estimated to be $4.5 \mathrm{kcal} / \mathrm{mol}$. The structural organization of Nafion membrane under different physiochemical conditions by invoking the balance between the elastic deformation of polymer matrix and various molecular interactions existing in the polymer has been discussed in the literature (Mauritz et al 1978).

Proton transport in Nafion has also been studied widely in the literature (Miyake et al 1983; Gebel et al 1993; Cappadonia et al 1995; Zadowzinski et al 1995; Wainright et al 1998; Choi et al 2005). Proton transport in Nafion depends on water content of the membrane. Although the precise mechanism for proton transfer in solvated form of Nafion is not completely understood, a qualitative picture is provided (Zawodzinski et al 1995) in figure 6. Generally, it is assumed that the state of water in Nafion membrane is not fixed. Some of the water is tightly bound to $-\mathrm{SO}_{3}^{-}$groups and is called chemicallybound water, which has lesser degree of hydrogen bonding than the bulk water; the latter is described as physically-bound water present in the central-pore region of Nafion membrane. The transfer of protons near pore sur-

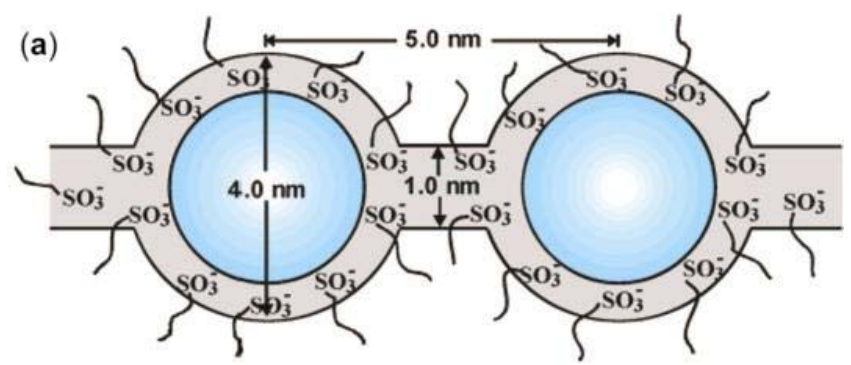

(b)

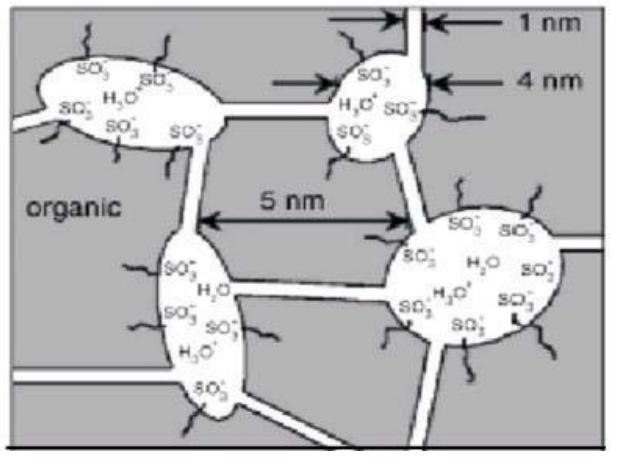

Figure 4. Cluster-network model for the interactions between polymer and water in Nafion membrane. 
Table 2. Physical properties of various commercially available cation-exchange membranes.

\begin{tabular}{|c|c|c|c|c|c|}
\hline Membrane & Membrane type & $\begin{array}{c}\text { IEC } \\
\text { (mequiv./g) }\end{array}$ & $\begin{array}{l}\text { Thickness } \\
(\mathrm{mm})\end{array}$ & Gel water (\%) & $\begin{array}{l}* \text { Conductivity } \\
(\mathrm{S} / \mathrm{cm})\end{array}$ \\
\hline $\begin{array}{l}\text { Asahi Chem } \\
\text { K } 101\end{array}$ & $\begin{array}{l}1 \text { Industry Company Ltd., } \\
\text { Sulfonated polyarylene }\end{array}$ & $\begin{array}{c}\text { da-ku, Tokyo, } \\
1.4\end{array}$ & $0 \cdot 24$ & 24 & $0 \cdot 0114$ \\
\hline $\begin{array}{l}\text { Asahi Glass } \\
\text { CMV } \\
\text { DMV } \\
\text { Flemion }\end{array}$ & $\begin{array}{l}\text { mpany Ltd., Chiyoda-ku, } \\
\text { Sulfonated polyarylene } \\
\text { Sulfonated polyarylene } \\
\text { Perfluorinated }\end{array}$ & $\begin{array}{c}\text { Japan } \\
2 \cdot 4 \\
- \\
-\end{array}$ & $\begin{array}{l}0 \cdot 15 \\
0 \cdot 15 \\
0 \cdot 15\end{array}$ & $\begin{array}{r}25 \\
- \\
-\end{array}$ & $\begin{array}{l}0 \cdot 0051 \\
0 \cdot 0071 \\
-\end{array}$ \\
\hline $\begin{array}{l}\text { Ionac Chem } \\
\text { MC } 3470 \\
\text { MC } 3142\end{array}$ & $\begin{array}{c}\text { Company, Sybron Corpo } \\
- \\
-\end{array}$ & $\begin{array}{l}\text { USA } \\
\qquad \begin{array}{r}1 \cdot 5 \\
1 \cdot 1\end{array}\end{array}$ & $\begin{array}{l}0 \cdot 6 \\
0 \cdot 8\end{array}$ & $\begin{array}{r}35 \\
-\end{array}$ & $\begin{array}{l}0 \cdot 0075 \\
0 \cdot 0114\end{array}$ \\
\hline $\begin{array}{l}\text { Ionics Inc., } \\
\text { 61AZL386 } \\
\text { 61AZL389 } \\
\text { 61CZL386 }\end{array}$ & 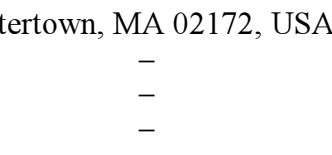 & $\begin{array}{l}2 \cdot 3 \\
2 \cdot 6 \\
2 \cdot 7\end{array}$ & $\begin{array}{l}0 \cdot 5 \\
1 \cdot 2 \\
0 \cdot 6\end{array}$ & $\begin{array}{l}46 \\
48 \\
40\end{array}$ & $\begin{array}{l}0 \cdot 0081 \\
- \\
0 \cdot 0067\end{array}$ \\
\hline $\begin{array}{l}\text { Du Pont Cor } \\
\text { N } 117 \\
\text { N } 901\end{array}$ & $\begin{array}{l}\text { any, Wilmington, DE } 198 \\
\text { Perfluorinated } \\
\text { Perfluorinated }\end{array}$ & $\begin{array}{l}0 \cdot 9 \\
1 \cdot 1\end{array}$ & $\begin{array}{l}0 \cdot 2 \\
0 \cdot 4\end{array}$ & $\begin{array}{r}16 \\
5\end{array}$ & $\begin{array}{l}0 \cdot 0133 \\
0 \cdot 01053\end{array}$ \\
\hline $\begin{array}{l}\text { Pall RAl Inc } \\
\text { R-1010 }\end{array}$ & $\begin{array}{l}\text { Iauppauge, NY 11788, Us } \\
\text { Perfluorinated }\end{array}$ & $1 \cdot 2$ & $0 \cdot 1$ & 20 & 0.0333 \\
\hline
\end{tabular}

*at $30^{\circ} \mathrm{C}$ and $100 \%$ relative humidity.

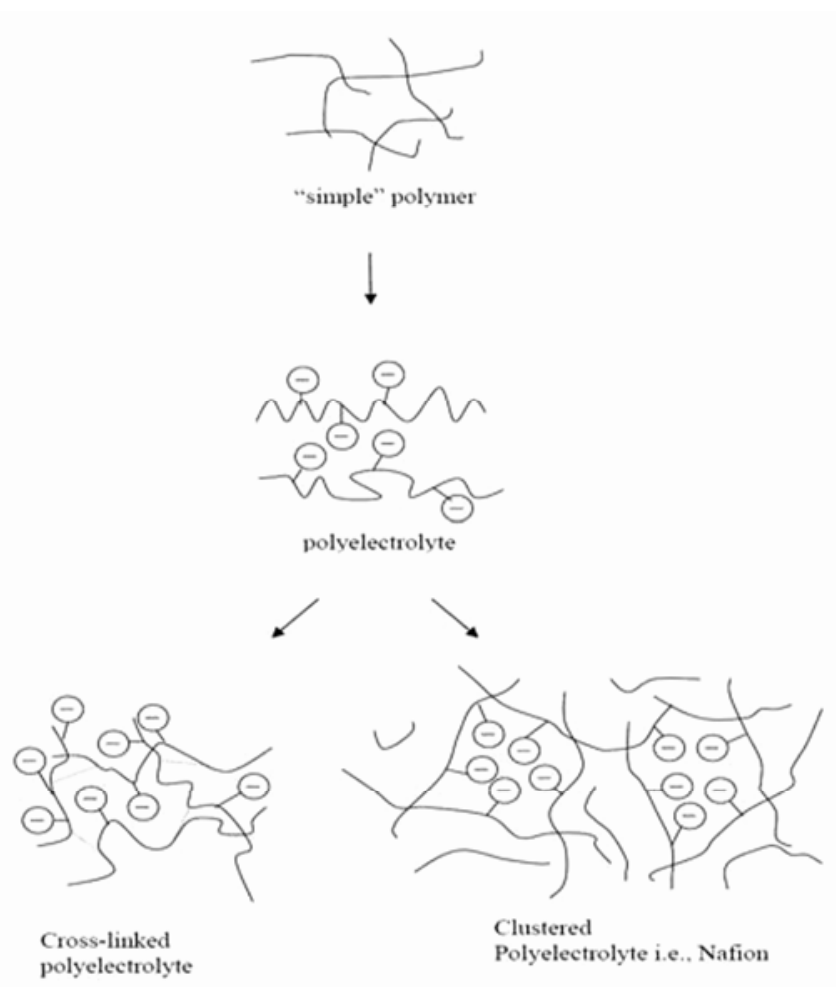

Figure 5. Simple structural conceptualization of cross-linked polyelectrolyte and clustered ionomeric system with anionic side chain.

face within $3-4 \AA$, which is roughly the thickness of water molecule, takes place through tightly-bound water molecules along the $-\mathrm{SO}_{3}^{-}$groups due to the electrostatic attraction.

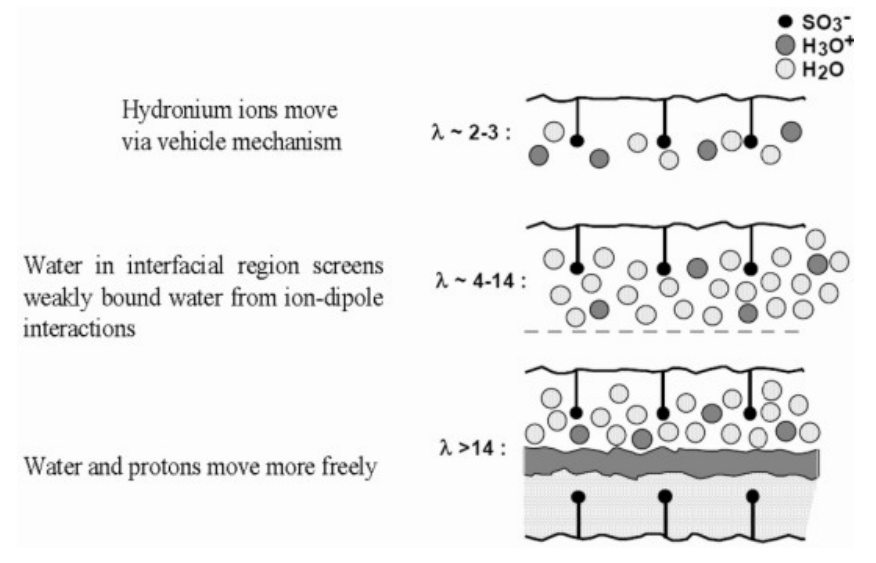

Figure 6. Qualitative picture of proton transport in Nafion.

As the membrane becomes saturated, the size of pores increases, increasing the bulk-like portion of water, which facilitates high rate of proton transfer in the middle of pores. Thus, the overall rate of proton transfer increases with pore radius until it reaches saturation where the average diameters of pores are $4-6 \mathrm{~nm}$. Proton conduction in Nafion occurs through the ionic channels formed by micro or nano phase separation between the hydrophilic proton exchange sites and the hydrophobic domains (Kreuer 2001). The present development of PEFCs is strongly linked to advantages and disadvantages of Nafion membrane under different operating conditions. Proton transfer in Nafion membrane relies on dissociation of protons from the constituent $-\mathrm{SO}_{3} \mathrm{H}$ groups in presence of water, which limits its application in PEFCs above $80^{\circ} \mathrm{C}$ (Chalkova et al 2005). 
Table 3. Conductivity values for solid-acid conductors.

\begin{tabular}{lc}
\hline Membrane system & $\begin{array}{c}\text { Comments on ionic conductivity } \\
\text { Nafion/silica }\end{array}$ \\
Nafion-titania & $\begin{array}{r}\text { Conductivity slightly lower to Nafion in high RH condition, improved conductivity at elevated } \\
\text { temperatures and lower RH values } \\
\text { Conductivity slightly lower to Nafion in high RH condition, improved conductivity at elevated } \\
\text { temperatures and lower RH values }\end{array}$ \\
Nafion-zirconia & $\begin{array}{r}\text { Conductivity similar to Nafion in high RH condition, improved conductivity at elevated } \\
\text { temperatures and lower RH values }\end{array}$ \\
Nafion/ZrP & $\begin{array}{l}\text { Improved conductivity and mechanical strength leading to better PEFC performance } \\
\text { Conductivity similar to Nafion in high RH condition, improved conductivity at elevated } \\
\text { temperatures and lower RH values }\end{array}$ \\
Nafion/CNT & $\begin{array}{r}\text { Conductivity slightly lower to Nafion in high RH condition, improved conductivity at elevated } \\
\text { temperatures and lower RH values }\end{array}$ \\
Nafion/Cesium phosphate & $\begin{array}{l}\text { Improved conductivity over Nafion. But suffers leaching of HPA. } \\
\text { Nafion/mordenite }\end{array}$ \\
Nafion/HPA (HPA: PWA, \\
SWA, PMA)
\end{tabular}

\section{Modified-Nafion membranes as electrolytes for PEFCs}

Conductivity of Nafion membranes often varies substantially depending on the system, membrane pre-treatment, and prevailing equilibrium parameters. At $100 \% \mathrm{RH}$, the conductivity of Nafion is generally about $0.1 \mathrm{~S} \mathrm{~cm}^{-1}$ at $60^{\circ} \mathrm{C}$ that drops by several orders of magnitude as the humidity is decreased. It is, therefore, mandatory to hydrate Nafion membranes to keep the ionic inclusions bridged. Transport of water is generally due to protonic defects and occurs through the breaking and forming of bonds. This is caused because the protonic defects weaken the intermolecular interaction affecting large variations in bond lengths combined with rapid breaking and forming of bonds.

Hydrophilic ceramic/inorganic fillers, such as $\mathrm{SiO}_{2}$, $\mathrm{TiO}_{2}, \mathrm{ZrO}_{2}$, zeolites, are added to Nafion matrix to retain water in the composite membrane at higher temperatures and low humidity (Miyake et al 2001; Song et al 2004, 2006; Jalani et al 2005; Klein et al 2005; Panero et al 2005; Borup et al 2007). These hydrophilic inorganic materials, when incorporated with Nafion, increase the binding energy of water as well as the number and strength of acid sites. The addition of inorganic fillers narrows the hydrophilic channels in Nafion matrix from 7.9 to $6.5 \mathrm{~nm}$, facilitating proton conduction. Besides, the filler particles have affinity to absorb and retain water in the Nafion matrix. Table 3 summarizes different inorganic additives/fillers that have been added to the Nafion matrix for operating PEFCs at high temperatures and low relative humidity values. Solid-acid proton conductors like zirconium phosphate, titanium phosphate, caesium phosphates and heteropolyacids have also been explored as additives to Nafion to facilitate proton transport at reduced or zero hydration levels in the matrix. Although this concept seems promising, the success so far remains limited and the interaction between the inorganic phase and proton conductor stands vaguely understood. The best possible way to test the limitations of these membranes is to study them as prototype MEAs in PEFCs. There are many other significant issues that need to be resolved before solid-acid membranes are used in PEFCs. These include standard operating parameters such as mechanical strength, durability, cyclability, synthetic conditions, and design issues including catalyst compatibility and scale-up.

\subsection{Nafion membranes with inorganic filler as electrolytes for PEFCs}

In order to realize optimum PEFC performance and to make the system simple, it is highly desired to operate PEFCs at elevated temperature $\left(>80^{\circ} \mathrm{C}\right)$ and reduced $\mathrm{RH}$ values at atmospheric pressure. To this end, Nafioncomposite membranes suitably modified with ceramic/ inorganic fillers, viz. $\mathrm{SiO}_{2}, \mathrm{TiO}_{2}, \mathrm{ZrO}_{2}$, zeolite etc are widely used to facilitate proton conductivity in stringent environmental conditions (Watanabe et al 1998; Adjemian et al 2002; Jung et al 2002; Aricò et al 2003; Ramani et al 2005; Sacca et al 2005).

In the literature, membranes with inorganic fillers have been fabricated by a variety of techniques. One method includes impregnating inorganic oxide particles as fine powders into the Nafion ionomers and fabricating a composite membrane (Mauritz et al 1995; Baglio et al 2005). Another method includes addition of a precursor, gene- 
rally as acidic metal alkoxides solution, into the Nafion ionomer for fabricating a composite membrane, and then converting the precursor material into the desired proton conducting oxide (Aparicio et al 2005; Lin et al 2005; Jiang et al 2006b). In most of the cases, solid polymer electrolyte, Nafion, is soaked in inorganic metal alkoxide precursor or alcoholic solution of one or more metal alkoxides till the desired amount of the inorganic filler permeates through the pores of Nafion (Miyake et al 2001; Adjemian et al 2002). After soaking the surface, the membrane is copiously rinsed to wash away surface metal alkoxide followed by hydrolyzing the metal alkoxide in the membrane with water. Incorporating the inorganic fillers into the polymeric matrix by above process may be inhomogeneous as, in such fillings, it is possible that some portions of the matrix may contain only a little oxide or no oxide at all. It is also possible to find enriched concentrations of filler particles in the bottom part of the membrane due to the sedimentation of heavier ceramic/inorganic fillers. As a result, the solid fillers in the composite membranes are devoid of imparting sufficient proton conductivity in the composite membrane under dry conditions.

In the literature, hydrophilic zirconia $\left(\mathrm{ZrO}_{2}\right)$ particles and its sulphate and phosphate forms have been considered as active filler materials with Nafion for the above stated purpose. The water uptake and proton conduction properties of the composite membrane depend on size and structure of the materials embedded with them. Sulfatepromoted super-acid zirconia $\left(\mathrm{S}-\mathrm{ZrO}_{2}\right)$ has been reported as an active ceramic filler with Nafion membrane to increase the water uptake property of the membrane and provide additional acidic sites for proton diffusion (Hogarth et al 2005; Thampan et al 2005; Zhai et al 2006; Navarra et al 2007). Zirconium phosphate as hydrophilic and proton conducting material has been incorporated into various polymer matrices (Bauer and Porada 2005; Hill et al 2006; Jiang et al 2006a; Boutry et al 2007). It is also noteworthy that proton conduction in these materials predominantly takes place by surface transport through the interlayer regions in the presence of water.

Nafion-zirconium phosphate composite membranes have been fabricated by a variety of techniques (Damay and Klein 2003; Alberti et al 2005). Conventionally, water absorbing pre-formed fine zirconia powder is dispersed in Nafion ionomer solution to form Nafionzirconia composite membrane. The composite membrane is then treated in phosphoric acid followed by drying at suitable temperature for forming Nafion-zirconium phosphate composite membrane. Another method includes cation exchange between the ionomer and zirconium cationic species followed by membrane treatment with phosphoric acid to precipitate zirconium phosphate within the hydrophilic regions of the ionomer. In an in situ preparation of the zirconium phosphate, phosphoric acid is reacted with either zirconyl chloride or with zirco- nium alkoxide at desired temperatures; zirconium phosphate, thus prepared, is embedded within Nafion ionomer to form a composite membrane.

Incorporating zirconium phosphate into the polymeric matrix by the aforesaid processes could result in a nonhomogeneous matrix with such fillers. It is also likely that phosphoric acid may not be covalently bound within the membrane. It is also possible to end-up with enriched concentrations of the phosphoric acid on the surface of the composite membrane, which when operated in the PEFC may cause leaching of the phosphoric acid along with the product water. Among the various aforesaid techniques for preparing Nafion-mesoporous zirconium phosphate composite membranes, only the in situ preparation of zirconium phosphate for embedding with Nafion ionomer to form a composite membrane appears attractive for avoiding the presence of any surface bound acid. But, even in this preparation, both low porosity and low internal-surface-area of zirconia particles limit the hydrophilicity of the composite membrane. In order to increase the porous nature of zirconium phosphate, efforts have been expended to develop mesoporous zirconium phosphate (MZP) materials either by hard-template approach or by surfactant-assisted route (Davis et al 1988; Dessau et al 1990; Estermann et al 1991; Haushalter and Mundi 1992; Khan et al 1996; Sayari et al 1996; Jimenez et al 1998; Castellon et al 1999). MZP as a surface-functionalized solid-super-acid-proton-conducting medium as well as inorganic filler with high affinity to absorb water helps fast proton-transport across the membrane electrolyte suitable for PEFC operation especially at low RH values.

\subsection{Nafion-silica composite membranes as electrolytes for PEFCS}

To obviate the aforesaid limitations, preparation of Nafionsilica composite membranes by embedding silica particles as inorganic fillers in perfluorosulfonic acid ionomer by a novel water hydrolysis process (Sahu et al 2007) is reported. In this process, a homogeneous, transparent and less viscous inorganic sol is first prepared by controlled water hydrolysis to silicon alkoxide without any external acidic or basic environment. Subsequently, the required amount of the sol is incorporated into the polymer matrix. The less viscous sol enters the fine pores of perfluorosulfonic acid (PFSA) and due to acidic nature of the latter forms $\mathrm{Si}-\mathrm{OH}$ network in the pores, which on heating at $90^{\circ} \mathrm{C}$ under vacuum form $\mathrm{Si}-\mathrm{O}-\mathrm{Si}$ linkages in the composite membrane. A transparent polymer film is thus obtained without any particle/phase segregation. The composite membranes have been tested in hydrogen/oxygen PEFCs at varying $\mathrm{RH}$ between $100 \%$ and $18 \%$ at elevated temperatures at atmospheric pressures.

Performance of $\mathrm{H}_{2} / \mathrm{O}_{2}$ PEFC employing Nafion-silica composite membranes is studied by obtaining the fuel 
cell polarization data as a function of varying load current-density. Figure 7 compares the polarization curves for the Nafion-silica composite and commercial Nafion1135 membranes under fully-wet condition $(\approx 100 \% \mathrm{RH})$ at $60^{\circ} \mathrm{C}$ under ambient pressure. In all the experiments, the flow rates for both the fuel and the oxidant are fixed so as to preclude any water retention in the cell. Nafionsilica composite membranes with varying silica content show better performance in relation to Nafion membranes. The peak power density of $720 \mathrm{~mW} / \mathrm{cm}^{2}$ for the PEFC is achieved with Nafion-silica (10 wt.\%) composite membrane as compared to $550 \mathrm{~mW} / \mathrm{cm}^{2}$ for the PEFC with Nafion-1135 membrane under identical operational conditions. Proton conductivity in the Nafion-silica composite membrane is attributed to protons that are transferred through hydrogen bonding with water-filled ion pores. However, an excess of silica phase in Nafion matrix reduces the PEFC performance due to electrode flooding in the PEFC. Accordingly, the peak power density for the PEFC with Nafion-silica (15 wt.\%) composite membrane is lower in relation to PEFC with Nafionsilica (10 wt.\%) composite membrane.

Polarization data for PEFCs with Nafion-1135 and Nafion-silica composite membranes under near-dry conditions $(\leq 18 \% \mathrm{RH})$ are shown in figure 8 . At these $\mathrm{RH}$ values, the humidification of hydrogen gas is inapt to operate PEFCs with pure Nafion membranes as the PEFCs yield a peak power-density of only about $30 \mathrm{~mW} / \mathrm{cm}^{2}$ at $100 \mathrm{~mA} / \mathrm{cm}^{2}$ primarily due to the poor conductivity of the Nafion membrane. By contrast, under identical conditions, PEFCs employing Nafion-silica composite membranes perform much better in relation to those with pristine-Nafion membranes. The performance of PEFCs with Nafion-silica composite membranes increases gradually with increasing silica content in the Nafion matrix. A peak power-density of $300 \mathrm{~mW} / \mathrm{cm}^{2}$ is achieved at
$1200 \mathrm{~mA} / \mathrm{cm}^{2}$ for the PEFC employing a Nafion-silica composite membrane with $15 \mathrm{wt} \%$ silica while operating at $60^{\circ} \mathrm{C}$ under atmospheric pressure. It is, therefore, quite obvious that PEFC performance is purely related to water-management. In commercial Nafion membranes, the limited availability of water at the anode, electroosmotic drag of water from anode to cathode and insufficient water back-diffusion from cathode to anode cause the membrane to dehydrate. The membrane dehydration is manifested with an increase in ohmic resistance of the cell leading to decreased cell performance. By contrast, in the case of composite Nafion membranes, due to water retention characteristics of the silica, such a problem is obviated.

\subsection{Nafion-mesoporous zirconium phosphate composite membranes as electrolytes for PEFCs}

Synthesis of mesoporous zirconium phosphate (MZP) by co-assembly of a tri-block copolymer, viz. pluronic-F127, as a structure directing agent and a mixture of zirconium butoxide and phosphorous trichloride as inorganic precursors has been recently reported (Sahu et al 2009). Nafion-MZP composite membrane is obtained by employing MZP as surface-functionalized solid-super-acidproton-conducting medium as well as inorganic filler with high affinity to absorb water and fast proton-transport across the electrolyte membrane even under low relative humidity conditions. The presence of large pores and high internal-surface-area ameliorates the hydrophilic character of the internal pore-surfaces and results in a solid super-acid exhibiting fast proton-conduction. MZP, thus synthesized, is impregnated with the Nafion ionomer to realize a proton-conducting composite membrane.

Figure 9 shows the FTIR spectra for the calcined zirconium phosphate with a strong sharp band centred at

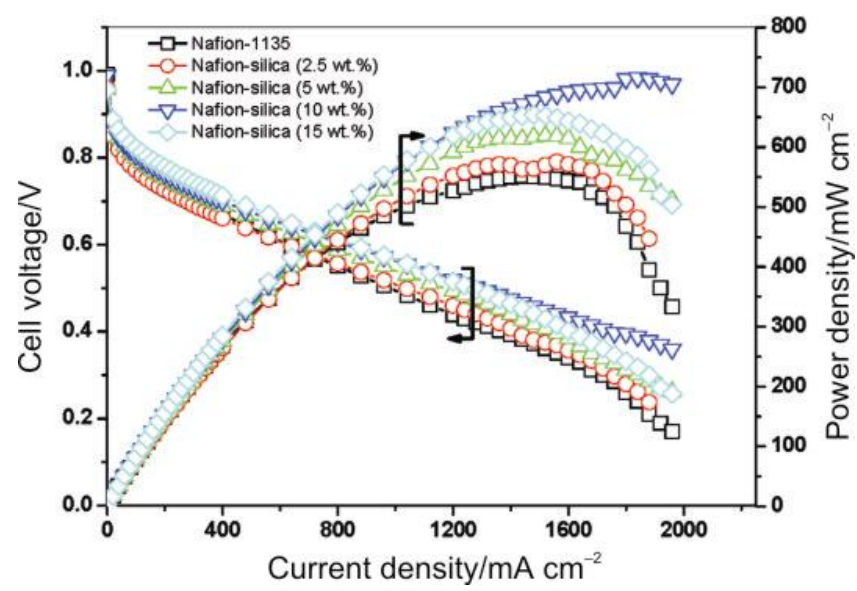

Figure 7. Performance of $\mathrm{H}_{2} / \mathrm{O}_{2}$ PEFC with Nafion-1135 and Nafion-silica composite membranes at $100 \% \mathrm{RH}$ under atmospheric pressure operating at $60^{\circ} \mathrm{C}$.

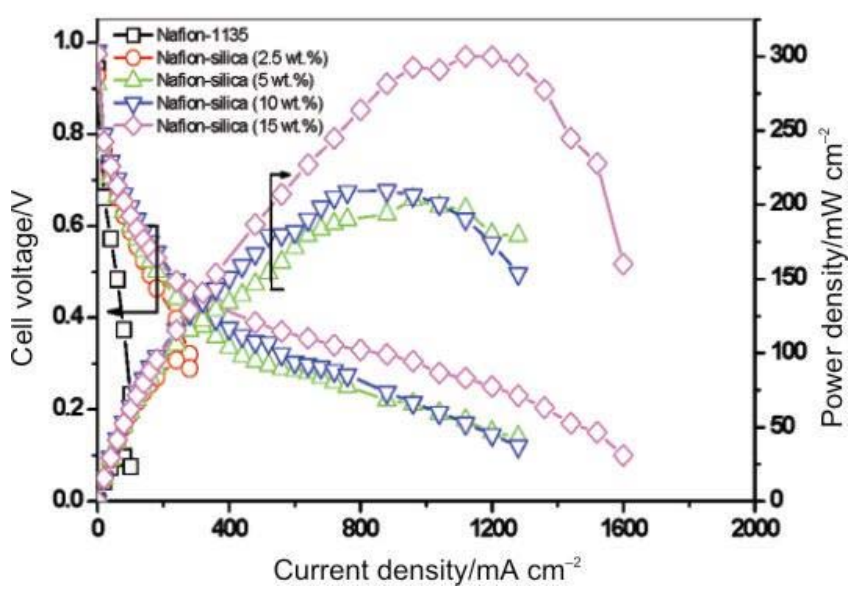

Figure 8. Performance of $\mathrm{H}_{2} / \mathrm{O}_{2} \mathrm{PEFC}$ with Nafion- 1135 and Nafion-silica composite membranes at $18 \% \mathrm{RH}$ under atmospheric pressure operating at $60^{\circ} \mathrm{C}$. 
$1070 \mathrm{~cm}^{-1}$ corresponding to $\mathrm{P}-\mathrm{O}$ stretching vibration. The broad peak at $2373 \mathrm{~cm}^{-1}$ corresponds to the $\mathrm{P}-\mathrm{O}-\mathrm{H}$ stretching vibration and the other broad band at around $3435 \mathrm{~cm}^{-1}$ is attributed to asymmetric $\mathrm{OH}$-stretching of water molecule while the weak peak at $1640 \mathrm{~cm}^{-1}$ indicates the bending of water molecule. The peak at $749 \mathrm{~cm}^{-1}$ indicates $\mathrm{P}-\mathrm{O}-\mathrm{P}$ symmetric stretching.

Figure 10 depicts the polarization curves for the PEFCs with Nafion-MZP composite membranes and commercial Nafion-1135 membrane under $\sim 100 \% \mathrm{RH}$ at $70^{\circ} \mathrm{C}$. PEFCs containing Nafion-MZP composite membranes with varying MZP content show better performance than the PEFC with pristine-Nafion membrane. Maximum proton conductivity with the composite membrane is attained at an intermediate loading of MZP. Peak power density of $725 \mathrm{~mW} \mathrm{~cm}^{-2}$ is achieved for the PEFC with Nafion-MZP (5 wt.\%) composite membrane in relation to $655 \mathrm{~mW} \mathrm{~cm}^{-2}$

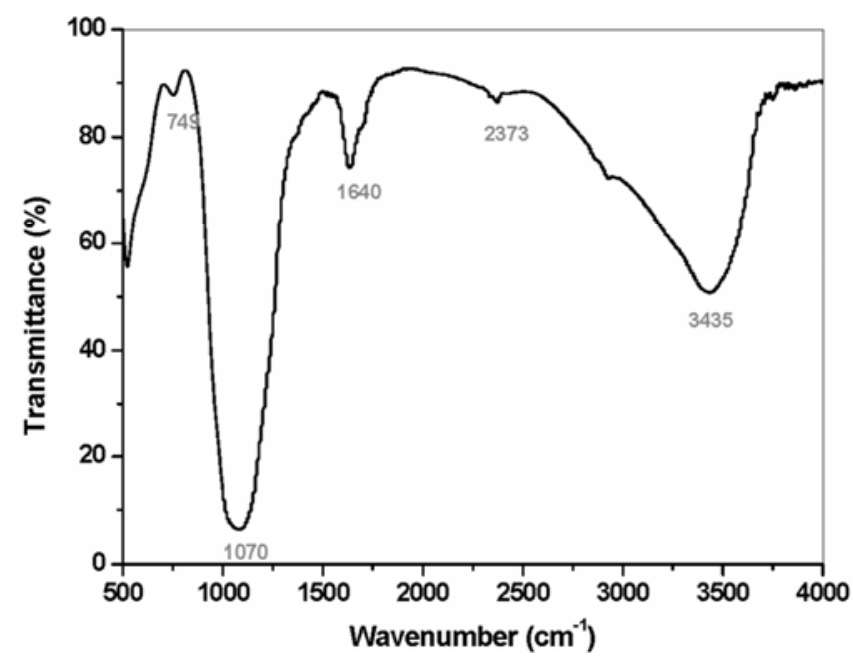

Figure 9. FTIR spectrum for MZP powder.

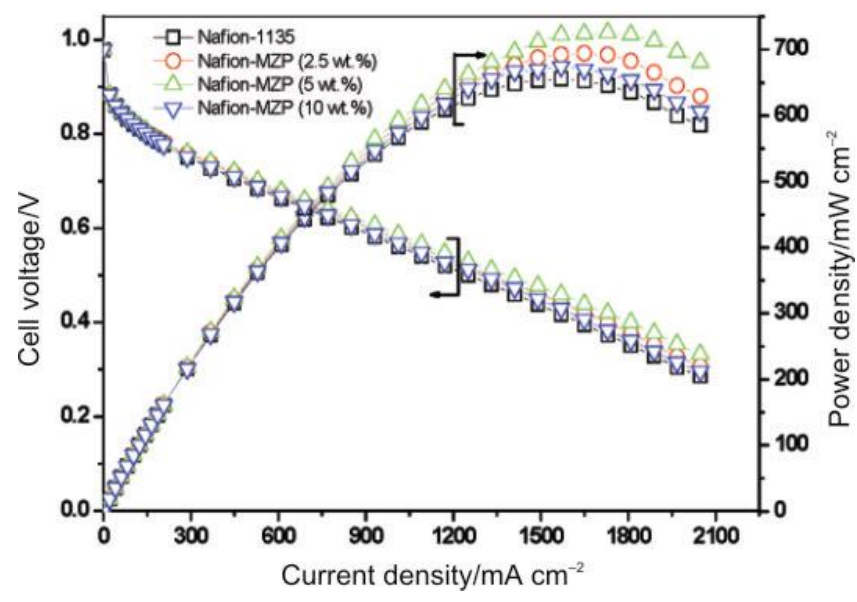

Figure 10. Performance of a $\mathrm{H}_{2} / \mathrm{O}_{2}$ PEFC employing Nafion1135 and Nafion-MZP composite membranes at $100 \% \mathrm{RH}$ at $70^{\circ} \mathrm{C}$ under atmospheric pressure. for the PEFC with Nafion-1135 membrane operating under identical conditions. Accordingly, it appears that the presence of MZP as a surface functionalized solid super-acid proton conducting medium in the Nafion matrix assists the Nafion-MZP composite membrane to achieve higher proton conductivity in relation to pristine-Nafion membrane.

Polarization data for PEFCs with Nafion-1135 and Nafion-MZP composite membranes under near-dry condition $(\sim 18 \% \mathrm{RH})$ are shown in figure 11 . At these $\mathrm{RH}$ values, PEFCs with pristine Nafion-1135 membranes yield a peak power-density of only about $224 \mathrm{~mW} \mathrm{~cm}^{-2}$ at $500 \mathrm{~mA} \mathrm{~cm}^{-2}$, primarily due to the poor conductivity of the Nafion membrane. By contrast, under identical conditions, PEFCs employing Nafion-MZP composite membranes perform much better. The performance of PEFCs with Nafion-MZP composite membranes increases gradually with increasing MZP content in the Nafion matrix. A peak power-density of $353 \mathrm{~mW} \mathrm{~cm}^{-2}$ is achieved at $1100 \mathrm{~mA} \mathrm{~cm}^{-2}$ for the PEFC employing a Nafion-MZP composite membrane with $5 \mathrm{wt} \% \mathrm{MZP}$ while operating at $70^{\circ} \mathrm{C}$ under atmospheric pressure.

Nafion-inorganic composite membranes exhibit lower resistance and hence PEFCs with such membranes sustain higher load current-densities particularly under low relative humidity conditions in relation to the pristine-Nafion membranes. This provides an alternative route to fabricate composite membranes with filler particles that absorb water and act as a water reservoir to keep the membrane wet even at low relative humidity values. These membranes help PEFCs to sustain periods of inlet-stream draught without excessive loss in membrane conductivity. Consequently, the humidification exigencies for PEFCs in an operating system are mitigated, which helps cutting system complexity and hence its cost.

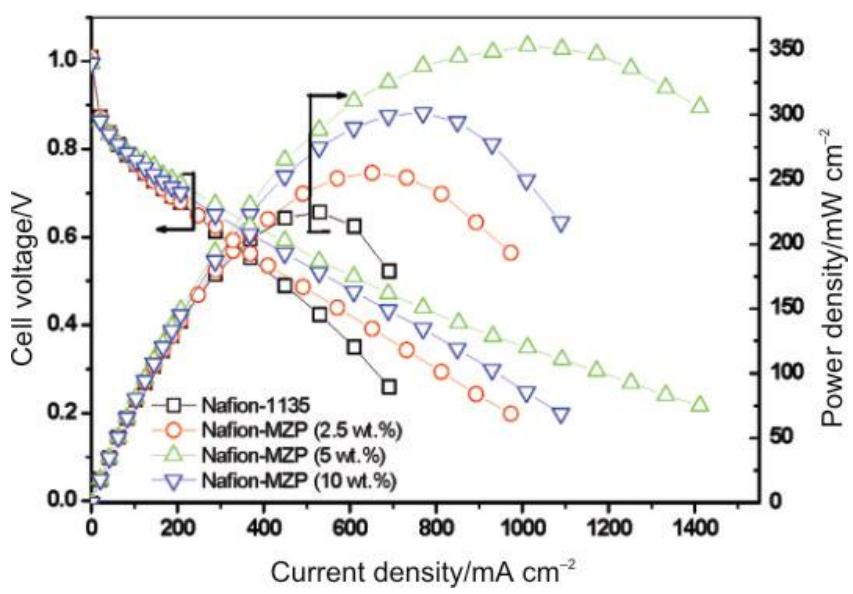

Figure 11. Performance of a $\mathrm{H}_{2} / \mathrm{O}_{2}$ PEFC employing Nafion1135 and Nafion-MZP composite membranes at 18\% RH at $70^{\circ} \mathrm{C}$ under atmospheric pressure. 


\section{Conclusions}

Polymer electrolyte fuel cells have reached a high level of development with applications ranging from cars to aerospace. But a stigma in their commercialization is their cost. To this end, it is most desirable to develop thermally stable and cost-effective polymer electrolyte membranes as substitute to Nafion. This article reviews various Nafion and Nafion-modified membranes for application in polymer electrolyte fuel cells. ModifiedNafion membranes perform better than pristine-Nafion membranes as electrolytes for PEFCs. Among the various modified-Nafion membranes, Nafion-inorganic composite membranes appear to be the most promising electrolytes for PEFCs.

\section{Acknowledgement}

Financial support from CSIR, New Delhi, is gratefully acknowledged.

\section{References}

Adjemian K T, Lee S J, Srinivasan S, Benziger J and Bocarsly A B 2002 J. Electrochem. Soc. 149 A256

Alberti G, Casciola M, Pica M, Tarpanelli T and Sganappa M 2005 Fuel Cells 5366

Aparicio M, Castro Y and Duran A 2005 Solid State Ionics 176 333

Aricò A S, Baglio V, Blasi A D and Antonucci V 2003 Electrochem. Commun. 5862

Baglio V, Aricò A S, Blasi A D, Antonucci V, Antonucci P L, Licoccia S, Traversa E and Fiory F S 2005 Electrochim. Acta 501241

Bauer F and Porada M W 2005 J. Power Sources 145101

Borup R et al 2007 Chem. Rev. 1073904

Boutry D T, Geyer A D, Guetaz L, Diat O and Gebel G 2007 Macromolecules 408259

Cappadonia M, Erning J W, Niaki S M S and Stimming U 1995 Solid State Ionics 7765

Castellon E R, Jimenez J J, Lopez A J, Torres P M, Barrado J R R, Jones D J and Roziere J 1999 Solid State Ionics 125 407

Chalkova E, Fedkin M V, Wesolowski D J and Lvov S N 2005 J. Electrochem. Soc. 152 A1742

Choi P, Jalani N H and Datta R 2005 J. Electrochem. Soc. 152 E84

Damay F and Klein L C 2003 Solid State Ionics 162-163 261

Davis M E, Montes C, Garces J and Crowder C 1988 Nature 331698

Dessau R M, Shirker J L and Higgins J B 1990 Zeolites 10522

Estermann M, McCusker L B, Baerlocher C, Merrouche A and Kessler H 1991 Nature 352320

Gebel G, Aldebert P and Pineri M 1993 Polymer 34333

Gottesfeld S and Zawodzinski T 1997 Adv. Electrochem. Sci. Eng. 5195

Grant P 2003 Nature 424129
Grot W G 1985 Chem. Ind. 19647

Haushalter R C and Mundi L A 1992 Chem. Mater. 431

Hickner M A, Ghassemi H, Kim Y S, Einsla B R and McGrath J E 2004 Chem. Rev. 1044587

Hill M L, Kim Y S, Einsla B R and McGrath J E 2006 J. Membr. Sci. 283102

Hogarth W H J, Costa J C D, Drennan J and Lu G Q 2005 J. Mater. Chem. 15754

Hsu W Y and Gierke T D 1983 J. Membr. Sci. 13307

Jalani N H, Dunn K and Datta R 2005 Electrochim. Acta 51 553

Jiang R, Kunz H R and Fenton J M 2006a Electrochim. Acta 51 5596

Jiang R, Kunz H R and Fenton J M 2006b J. Membr. Sci. 272 116

Jimenez J J, Torres P M, Pastor P O, Castellon E R, Lopez A J, Jones D J and Roziere J 1998 Adv. Mater. 10812

Jung D H, Cho S Y, Peck D H, Shin D R and Kim J S 2002 J. Power Sources 106173

Khan M I, Meyer L M, Haushalter R C, Schweitzer A L, Zubieta J and Dye J L 1996 Chem. Mater. 843

Klein L C, Daiko Y, Aparicio M and Damay F 2005 Polymer 464504

Kreuer K D 2001 J. Membr. Sci. 18529

Lin C W, Thangamuthu R and Chang P H 2005 J. Membr. Sci. 254197

Mauritz K A and Moore R B 2004 Chem. Rev. 1044535

Mauritz K A, Hora C J and Hopfinger A J 1978 Prep. Am. Chem. Soc. Div. Polym. Chem. 19324

Mauritz K A, Stefanithis I D, Davis S V, Scheez R W, Pope R K, Wilkes G L and Huang H H 1995 J. Appl. Polym. Sci. 55 181

Mench M M 2008 Fuel cell engines (New Jersey: Wiley)

Miyake H, Matsuyama M, Ashida K and Watanabe K $1983 \mathrm{~J}$. Vac. Sci. Technol. 11447

Miyake N, Wainright J S and Savinell R F $2001 \mathrm{~J}$. Electrochem. Soc. 148 A898

Navarra M A, Croce F and Scrosati B 2007 J. Mater. Chem. 17 3210

Panero S, Fiorenza P, Navarra M A, Romanowska J and Scrosati B 2005 J. Electrochem. Soc. 1522400

Ramani V, Kunz H R and Fenton J M 2005 Electrochim. Acta 50 1181

Roziere J and Jones D J 2003 Ann. Rev. Mater. Sci. 33503

Sacca A et al 2005 J. Power Sources 142385

Sahu A K, Selvarani G, Pitchumani S, Sridhar P and Shukla A K 2007 J. Electrochem. Soc. 154123

Sahu A K, Pitchumani S, Sridhar P and Shukla A K 2009 Fuel Cells 9139

Sayari A, Moudrakovski I, Reddy J S, Ratcliffe C I, Ripmeester J A and Preston K F 1996 Chem. Mater. 82080

Shukla A K and Raman R K 2003 Annu. Rev. Mater. Res. 33 155

Song J M, Miyatake K, Uchida H and Watanabe M 2006 Electrochim. Acta 514497

Song M K, Park S B, Kim Y T, Kim K H, Min S K and Rhee H W 2004 Electrochim. Acta $\mathbf{5 0} 639$

Springer T E, Zawodzinski T A and Gottesfeld S 1991 J. Electrochem. Soc. 1382334

Thampan T M, Jalani N H, Choi P and Datta R 2005 J. Electrochem. Soc. 152316 
Tsuchiya H and Kobayashi O 2004 Int. J. Hydrogen Energy 29 985

Wainright J S, Fontanella J J, Wintersgill M C, Savinell R F and Litt M 1998 Electrochim. Acta 43289

Watanabe M, Uchida H, Seki Y and Emori M 1998 J. Phys. Chem. B102 3129
Yeo S C and Eisenberg A 1997 J. Appl. Polym. Sci. 21 875

Zadowzinski T, Davey J, Valerio J and Gottesfeld S 1995 Electrochim. Acta 40297

Zhai Y, Jhang H, Hu J and Yi B 2006 J. Membr. Sci. 280 148 